\title{
Breeding avifauna of Opava Mountains and their foothills, Opole Silesia
}

Grzegorz Kopij

Breeding avifauna of Opava Mountains and their foothills, Opole Silesia. - Acta Mus. Siles. Sci. Natur., 68: 233-248, 2019.

\begin{abstract}
In 2010, an attempt was made to quantify bird species breeding in the Opava Mts. and their foothill (c. $135 \mathrm{~km}^{2}$, including c. $40 \mathrm{~km}^{2}$ [31\%] of forests). The area is situated in the extreme south of Opole Silesia, SSW Poland. For most non-passerine species, total counts were made for the whole area (distribution of their breeding pairs is shown on maps), while for most passerine species, semiquantitative studies were conducted. A total of 116 breeding and two probably breeding bird species were recorded. Changes in breeding avifauna of the area during the years 1880-2010 are also analysed based on literature search. A total of 134 breeding bird species were recorded over the 130 years. During the years 1990-2010, decreae in numbers has been evidenced for the following species: Perdix perdix, Tetrastes bonasia, Tyto alba, Athene noctua, Corvus frugilegus, and Nycifraga caryocatactes, In the same period, increase in numbers has been documented for species such as: Accipiter gentilis, Falco tinnunculus, Columba oenas, Jynx torquilla, Dryocopus martius, Picus canus, Picus viridis, Motacilla cinerea, Luscinia megarhynchos, Phoenicurus phoenicurus, Saxicola rubicola, Locustella naevia, Locustella fluviatilis, Corvus corax and Corvus cornix. Opava Mts. and its foothills constitute an imporant conservation area. Fifteen species listed in Annex I of the Bird Directive of the E.U. were recorded there, including a sizable population of Ficedula albicollis.
\end{abstract}

Key words: cenzuses, population trends, Sudeten Mts., Głuchołazy, Biskupia Kopa, ladscape parks.

\section{Introduction}

Opava Mts. are the only mountains in Opole Silesia, SSW Poland, and as such they have attracted attention of tourists as well as ecologists, conservationists, botanists and zoologists in the last few decades. First observations on birds of the Polish part of the Opava Mts. were made in the end of $19^{\text {th }}$ and at the beginning of the $20^{\text {th }}$ century (Thiemann 1887 , Kollibay 1906, Pax 1925, Jitschin 1938). However, quantitative data from this period refer only to a few rare species, such as Bonasia bonasia, Picus canus, and Cinclus cinclus.

An attempt to estimate numbers of some rare species in Opava Mts. was undertaken again at the end of that century, when a general survey was conducted across the whole area of Silesia in 1978-1987 (Dyrcz et al. 1991). Among others, the following species were subject of this survey: Accipiter gentilis, A. nisus, Falco tinnunculus, Columba oenas, Picus canus, Alcedo atthis, Cinclus cinclus, Motacilla cinerea, Saxicola torquata, Remiz pendulinus, Corvus corax.

The entire breeding avifauna of the Opava Mts. was a subject of a thorough investigation in the 1990-92 (Kopij 1994), and 1995-96 (Hebda 2001). Breeding avifauna of the foothills was also under Kopij's (1999) survey conducted during the years 1989-1992. Although the numbers of breeding pairs of less common species (mainly non-passerines) were estimated quite precisely, for most common species (mostly passerines), only rough semi-quantitative data were presented.

The aim of this study was to estimate number of breeding pairs of all uncommon species, and to estimate relative abundance of the remaining common species, especially those breeding in forests. The study area has been extended further north to the Opava Mountains Lanscape Park, as to include also neighbouring lowlands. An attempt is also made here to determine population trends for some species during the last 130 years. 


\section{Study area}

The study area comprises Polish part of the Opava Mountains and their foothills within boundaries as defined by Kondracki (1994), i.e. to Prudnik River in the north, and Biała Gluchołaska in the west. It excudes, therefore, the neighbouring areas of the same mountains in the Czech Republic (Kopij 2005, 2006, 2007a, 2007b) and the hilly areas west of Głuchłazy (Kopij 1996). The town Głuchołazy within its administrative boundaries is included in the study area, while the town Prudnik is excluded, except for its southern not built-up peripheries. Breeding avifauna of Prudnik town was, however, a subject of thorough investigation by Kopij (1995, 2013c).

The total surface of such defined study area is c. $135 \mathrm{~km}^{2}$. It is administered by two districts: Nysa (with Głuchołazy caunty) in western part, and Prudnik (with Prudnik and Lubrza caunties) in eastern part. The study area includes, therefore, the whole Opava Mountains Landscape Park, with its buffer zone. It is a part of the larger Euroregion Praded/Pradziad/Alvater (Kopij 2017a).

Forests occupy c. $40 \mathrm{~km}^{2}$ (c. $31 \%$ of the total surface area); in the western part: Chrobry. Mt. (c. 650 ha), Bishop's Mt. (with Silvery Mt., and Castel Mt.) - c. 1100 ha, and Olszak Mt. with Charbielin Forest - c. 750 ha; in the eastern part: Prudnicki Forest (c. 1000 ha) and Trzebina Forest (c. 500 ha). Bishop's Mt. is dominated by the spruce Picea abies, and Trzebnicki Forest by the oak Quercus robur, while other forest compelxes represent mixed forests (Dubiel 1993, Kopij 2013b).

The farmland dominates the foothills. Most of the area is covered with cultivated arable fields with wheat, rape and beat as main crops.

The following villages are located in western part (Nysa district): Konradów, Skowronków, Podlesie (with Gęstwina), Jarnołtówek and Pokrzywna; in the estern part: Moszczanka, Łąka Prudnicka, Wieszczyna, Dębowiec, Chocim, Trzebina, Dytmarów and Krzyżkowice.

There are small fish-ponds near Krzyżkowice, between Krzyżkowice and Dytmarów, west of Trzebina, and in Niemysłowice (together with gravel-pit); and water reserviors in Jarnołtówek, Pokrzywna, and in southern periphery of Prudnik. The main rivers are Biała Głuchołaska to the west and Prudnik to the north. Złoty Potok with Bystry Potok are the main tributaries of Prudnik, while Olszanka is the main tributary of Biała. All the rivers belong to the Nysa Kłodzka river basin.

\section{Material and methods}

Studies were carried out from 18 March to 20 July 2010. In total, 26 days were devoted to these studies, which were conducted on foot in forests and in river valleys, while on bicycle in open areas. Special attention was paid to uncommon species, determining in each case the breeding status of each encountered bird (according to atlasing citeria; eg. Sikora et al. 2007). Two records in the same site (separated by an interval of at least two weeks) of a bird showing breeding or/and territorial behaviour were interpreted as occupied territory (=breeding pair), as were also two simultanously singing males in an optimal breeding habitat (Bibby et al. 1993).

Based on literatute, four study periods were distinguished:

I: 1906-1938, based on Kollibay (1906), Pax (1925) and Jitschin (1938)

II: $1990-92$, based on Kopij (1994)

III: 1995-96, based on Hebda (2001).

IV: 2010, based on this study and Kopij (2013a, 2014a, 2014b).

Quantitative studies on birds breeding in forests were conducted from 18 March to 14 July 2010 by mean of the line transec method (Bibby et al. 1992). A total of 16 days ( 86 hours and $50 \mathrm{~min}$.) were devoted for counting (Table 1). Additional 10 days were devoted for study in farmlands and human settlements.

In total 26 days were spent in the field: March: 19, 20, 22, 23, 24; April: 4, 7, 8, 9, 24; May: 22, 24, 25, 26, 28, 29, 30; June: 17, 18, 19, 21, 22, 23; July: 10, 23, 25.

Table 1. Time expenditure for counting birds by means of the line transect method in forests.

\begin{tabular}{|l|c|c|c|c|c|}
\hline & $\begin{array}{c}\text { Góra } \\
\text { Chrobrego }\end{array}$ & Kopa Biskupia & $\begin{array}{c}\text { Olszak and } \\
\text { Charbielin F. }\end{array}$ & $\begin{array}{c}\text { Prudnicki } \\
\text { Forest }\end{array}$ & $\begin{array}{c}\text { Trzebina } \\
\text { Forest }\end{array}$ \\
\hline March & $6 \mathrm{~h}^{\prime}$ & $6 \mathrm{~h} 30^{\prime}$ & $3 \mathrm{~h} 30^{\prime}$ & $6 \mathrm{~h} 20^{\prime}$ & $5 \mathrm{~h} 15^{\prime}$ \\
\hline April & $2 \mathrm{~h} 55^{\prime}$ & $8 \mathrm{~h} 15^{\prime}$ & $8 \mathrm{~h} 20^{\prime}$ & $6 \mathrm{~h} 00^{\prime}$ & \\
\hline May & $5 \mathrm{~h} 00^{\prime}$ & $8 \mathrm{~h} 30^{\prime}$ & & $7 \mathrm{~h} 30^{\prime}$ & $5 \mathrm{~h} 20^{\prime}$ \\
\hline June & & & $2 \mathrm{~h} 30^{\prime}$ & & $4 \mathrm{~h} 05^{\prime}$ \\
\hline Total & $14 \mathrm{~h} 35^{\prime}$ & $23 \mathrm{~h} 25^{\prime}$ & $14 \mathrm{~h} 20^{\prime}$ & $19 \mathrm{~h} 50^{\prime}$ & $14 \mathrm{~h} 40^{\prime}$ \\
\hline
\end{tabular}




\section{SYSTEMATIC LIST OF SPECIES}

Cygnus olor. On 17.06.2010, 1 adult with 5 pulli were observed in a water reservoir S of Prudnik. In the same year, another pair without nest was recorded in a fish-pond near Krzyżkowice.

Anas platyrhynchos. Fairly common on rivers, canals, and fish-ponds. 23.06 .2010 c. 60 non-breeding individuals were recorded in fish-ponds between Dytmarów and Krzyżkowice.

Tachybaptus ruficollis. On 04.04.2010, two males in a breeding display were observed in fish-ponds SW of Wieszczyna.

Podiceps cristatus. On 17.06.2010, a pair with 2 pulli was recorded in a water reservoir S of Prudnik.

Perdix perdix. In 1990-96, only few pairs were recorded (Kopij 1994, Hebda 2001); in 2010 not recorded at all.

Coturnix coturnix. In 2010, 5 pairs were recorded (Fig. 1).

Phasianus colchicus. Fairly common in farmlands.

Tetrastes bonasia. According to Kollibay (1906), it nested near Jarnołtówek and Pokrzywna, where 4 pairs were recorded in an area of 500 ha forests in 1880. However, it was not recorded during the years 1945-1995 and in 2010 (Dyrcz et al. 1991, Kopij 1994, Hebda 2001). On 16.08.2001 one individual was observed on Biskupia Kopa (Kopij, Profus 2014).

Ciconia nigra. In the years 1970-1995 one pair nested near Pokrzywna (Bednorz 1974, Kopij 1994, Hebda 2001, Kopij 2011), and during the years 1978-87, another one near Trzebina (Dyrcz et al. 1991). In 2010 not recorded.

Ciconia ciconia. During the years 1978-87, 9 nests were occupied (Dyrcz et al. 1991, Kopij 1991). In the subsequent years the numers remained stable (Kopij 1991, 1992, 1994, 1999, 2003, 2017, Kopij et al. 2001). In 2010, 6 breedidng pairs: Moszczanka - 2 pairs (Moszczanka 98: 2009: HPm2; 2010: HE2; HPmx.); Trzebina (2010: HPo(x)); Skrzypiec (2010: HPo(x)), Dytmarów and Wierzbiec; seven other pairs nested without breeding success (Fig. 2).

Pernis apivorus. During the years 1978-87 nested near Pokrzywna (Dyrcz et al. 1991). In 1995, one probably breeding pair was recorded on Chrobry Mt. near Przylesie (Hebda 2001). In 2010 not recorded.

Circus aeruginosus. On 17.06.2010 one female was observed while hunting in a farmland between Wierzbiec and Moszczanka.

Accipiter gentilis. According to Thiemann (1887) it nested ('spärlich') near Głuchołazy. During the years 197887 only one pair was recorded in Trzebina Forest (Dyrcz et al. 1991). In 2010 - 9 occupied territories, including 3 in Prudnik Forest (Fig. 3).

Accipiter nisus. On 23.03.2010 and 4.4.2010 a hunting individual was observed in a dense young spruce-larch forest around a fish-pond near Wieszczyna (Fig. 4).

Buteo buteo. In 2010, 32 occupied territories were mapped in the whole study area (Fig. 5).

Aquila pomarina. In 1997 one probably breeding pair was recorded in Charbielin Forest (Hebda 2001). In 2007, a nest with chicks was found near Osoblaha in the Czech Republic, close to the Czech/Polish border near Racławice Śląskie (Kondělka \& Petro 2007). In 2010 not recorded.

Falco tinnunculus. Recorded in Głuchołazy, where 3 pairs nested in 2010 (Kopij 2014b), and in Prudnik, where 4 pairs were recorded (Kopij 2013c) (Fig. 4). During the years 1978-87 four breeding sites were recorded (Dyrcz et al. 1991)

Falco subbuteo. In 1880 and 1881, breeding was recorded near Prudnik (Kutter \& Kollibay 1882, 1883). During the years 1978-87 breeding pair was recorded near Gluchołazy (Dyrcz et al. 1991). In 2010 breeing pair was recorded in Wężowa Góra (363 m a.s.1.) in Trzebina Forest (Fig. 4).

Grus grus. On 21.06.2010 one individual was passing along Złoty Potok near the water reservoir in Pokrzywna. In 2008, two breeding pairs were recorded around fish-ponds near Slezské Pavlovice in Czech Republic, just near the Polish/Czech border near Krzyżkowice (Kondělka \& Petro 2008). Not recorded as breeding before 2008 (Kollibay 1906, Pax 1925, Dyrcz et al. 1991).

Crex crex. Not recorded during the years 1978-87 (Dyrcz et al. 1991). In 2010, one singing male was heard on Złoty Potok near Pokrzywna.

Gallinula chloropus. In 1878, it was a common breeding species near Prudnik (Kutter \&, Kollibay 1882). During the years 1989-1992, 2-3 pairs were recorded in a gravel-pit in Niemysłowice (Kopij 1999). In 2008-2010 2-4 pairs were recorded in a water reservior S of Prudnik; 1 pair in water reservoir above Jarnołtówek (21.06.2010: 1 ad. and 2 pulli); 1-2 pairs in fish-ponds between Krzyżkowice and Dytmarów; 1 pair in a fish-pond W of Trzebina.

Fulica atra. In 1878, it was a common breeding species near Prudnika (Kutter \& Kollibay 1882). For the years 1989-92 the species was erronously omitted in Kopij (1999); in those years 3-5 pairs nested in a gravel-pit in Niemysłowice, and 2 pairs in a water reservoir S of Prudnik. During the years 2008-2010, 4-5 pairs nested in fish-ponds in Niemysłowice, 2 pairs in the water reservoir S of Prudnik, and 1 pair in a fish-pond $\mathrm{W}$ of Trzebina. 
Charadrius dubius. Kutter and Kollibay (1882) recorded it as breeding near Prudnik. During the years 1978-1987 breeding sites were localised on the Prudnik River below Dytmarów and near Skrzypiec (Dyrcz et al. 1991). In 1989-1992 one pair was recorded in a sand-pit near Jasiona (Kopij 1999), where it nested also in 2010. Single breeding pairs were also recorded in 2010 on Prudnik River just above the Polish/Czech border, and near Dytmarów.

Vanellus vanellus. In 2010, 4 breeding pairs were recorded on the Prudnik River, and one pair in arable grounds NW of Wieszczyna (Fig. 1).

Scolopax rusticola. According to Kutter and Kollibay (1882) and Kollibay (1906) it nested near Pokrzywna and Jarnołtówek. Not recorded during the years 1978-87 (Dyrcz et al. 1991). On 19.03.2010, it was observed in a suitable breeding habitat in Charbielin Forest, but probably it was there on passage.

Chroicocephalus ridibundus. In 2010, two breeding pairs were recorded in a water reservoir S of Prudnik; and 23 breeding pairs in a fish-pond in Niemysłowice.

Sterna hirundo. In 2010, possibly a breeding pair was recorded in a fish-pond between Dytmarów and Krzyżkowice.

Columba livia f. domestica. As a breeding species recorded only in Prudnik (50-80 pairs; Kopij 2013b) and in Głuchołazy (30-50 par; Kopij 2014b).

Columba oenas. During the years 1978-87 known only from one site near Pokrzywna (Dyrcz et al. 1991). In 2010, 4 sites with 9 calling males were mapped (Fig. 6). First arrival date: 19 March 2010 in Olszak Mt.

Columba palumbus. It comprises $0.5-1.5 \%$ of all breeding pairs in forests. In Prunik town, more than 100 pairs were recorded in 2010, including 58 pairs in a loose colony in the urban park (Kopij 2013b). In Głuchołazy 3-6 pairs were recorded in 2010 (Kopij 2014b). First arrival date: 19 March 2010 in Niemysłowice Forest.

Streptopelia decaocto. Common in human settlements: Prudnik - 70-100 pairs (Kopij 2013); Głuchołazy - 51 pairs, including 12 pairs in the city centre (Kopij 2014b); Trzebina - 7, Krzyżkowice - 2 (Kopij 2014a); Konradów - 9, Jarnołtówek - 1 pair only (in the village center), Pokrzywna - 1 pair (near Chrobry Bldg.); Moszczanka-Łąka Pr. - 14 pairs. Not recorded in small villages: Wieszczyna, Dębowiec, Chocim, Podlesie and Gęstwina (Kopij 2014a, 2014b).

Streptopelia turtur. In 2010, 38 pairs were recorded (Fig. 6).

Cuculus canorus. In 2010, 23 male's territories were located (Fig. 7).

Tyto alba. In 2010 - not recorded. In the past, it nested in Głuchołazy, Jarnołtówek, Łąka Prudnicka, and Trzebina (Kopij 1990).

Athene noctua. During the years 1978-1992 single pairs nested in Łąka Prudnicka and Jasiona (Dyrcz et al. 1991, Kopij 1999).

Strix aluco. Fairly common.

Bubo bubo. In 1995 recorded as breeding in Kopa Biskupia (Hebda 1997).

Asio otus. Uncommon breeding resident.

Apus apus. In 2010, 50-100 pairs nested in Prudnik (Kopij 2013); 34-50 pairs in Głuchołazy (Kopij 2014b); and 4 pairs in Podlesie (Kopij 2014b).

Alcedo atthis. In 1880, it was 'fairly common resident near Prudnik' (Kutter \& Kollibay 1882). During the years 1978-87 one pair was nested on Prudnik near Dytmarów (Dyrcz et al. 1991), while in 2010 one pair was recorded on Prudnik near Niemysłowice.

Coracias garrulus. In 1880, it was recorded as a breeding species near Prudnik (Kutter \& Kollibay 1882). However, Kollibay (1906) already did not confirm it in the whole Prudnik Land, including Opava Mts.

Upupa epops. 25 July 2010 calling male was heard in Konradów near Augusta Victoria's Monument (Kopij 2014b); and 8 April 2010 another male was heard in a farmland S of Moszczanka-Łąka Prudnicka. Not recorded during the years 1978-87 (Dyrcz et al. 2010).

Jynx torquilla. In 2010, 6 breeding pairs were recorded (Fig. 8).

Picus canus. According to Kollibay (1906), it nested near Głuchołazy. However, during the years 1978-87 it was not discovered in Opava Mts. at al (Dyrcz et al. 1991), being probably overlooked, as in 2010, 8 pairs were recorded (Fig. 9).

Picus viridis. In 2010, 6 pairs were recorded (Fig. 9).

Dryocopus martius. In 2010, 14 pairs were recorded (Fig. 9).

Dendrocopos major. A dominant species in Bishop's Mt., Olszak Mt. and Charbielin Forest; subdominant elsewhere.

Dendrocopos medius. In 2010, 11 pairs were recorded (Fig. 8)

Dendrocopos minor. In 2010, 7 occupied territories were located (Fig. 8).

Alauda arvensis. Common in famlands.

Lulula arborea. 24.03.2010, a singing male was heard in Trzebina Forest near the Polish/Czech border.

Hirundo rustica. Common in human settlements. In 2010 in Głuchołazy - 10-20 pairs (Kopij 2014b); at least each 20 pairs in the following villages: Konradów, Łąka Pr., Moszczanka, Trzebina; each few pairs in Jarnołtówek, Pokrzywna, Podlesie and Gęstwinia (Kopij 2014b). 
Delichon urbica. In 2010: Głuchołazy - 100-200 pairs (Kopij 2014b); Gęstwina on Oleśnica River - 73 nests (Kopij 2014b); Trzebina, - c. 30 nests; Jarnołtówek, 'Ziemowit' - c. 20 pairs. A few pairs nested in most other villages.

Anthus trivialis. In Trzebina Forest it composed 2.4\% of all breeding birds; $0.1-1.2 \%$ elsewhere.

Anthus campestris. In 2010, probably breeding in a sand-pit between Skrzypiec and Trzebina. In the same site, it was recorded also in 1978-1987 (Dyrcz et al. 1991).

Anthus pratensis. In 2010 not recorded. In 1990-92, single pairs were nested near Trzebina and Chocim (Kopij 1994).

Motacilla flava. Fairly common in farmlands. In 2010, at leat 10 breeding pairs.

Motacilla cinerea. During the years 1978-87: nested only at two sites: on Biała Głuchołaska near Głuchołazy and on Złoty Potok near Pokrzywna (Dyrcz et al. 1991). During the years 1995-1996: 12-13 pairs (Hebda 2001); 2000-2007: 22-23 pairs, including 7 pairs on Złoty Potok, 7 pairs on Biała Głuchołaska and 5 pairs on Bystry Potok (Czapulak et al. 2008). The numbers from 2000-2007 were probably overestimated (too staggered study period). In 2010, 17 pairs were recorded (Fig. 10).

Motacilla alba. Fairly common, mosty in human settlements: Głuchołazy - 5-7 pairs (Kopij 2014b), PokrzywnaJarnołtówek - 3 pairs (Kopij 2014b), Łąka Prudnicka-Moszczanka - 2 pairs (Kopij 2014a).

Cinculs cinclus. According to Kollibay (1906), it nested on Złoty Potok in Pokrzywna, and on Biała Głuchołaska in Głuchołazy. During the years 1978-87 also known only from this site (Dyrcz et al. 1991). In 2010 r. -7 breeding pairs were recorded, including 4 pairs on Biała Głuchołaska, 2 pairs on Złoty Potok and one pair on Bystry Potok (Fig. 11).

Troglodytes troglodytes. Common in forests.

Prunella modularis. Fairly common in forests.

Erithacus rubecula. Everywhere in forests a dominant species (in particular forests: $6.9-11.7 \%, x=8.1 \%$ ).

Luscinia megarhynchos. In 2010, 20 breeding pairs were recorded (Fig. 12). Not recorded in the vicinities of Głuchołazy, Jarnołtówek and Pokrzywna.

Phoenicurus ochruros. It nested mainly in human settlements. In 2010: Prudnik - 20-40 pairs (Kopij 2013b); Głuchołazy - 27 pairs (Kopij 2014b), Trzebina - 8 pairs (Kopij 2014a), Pokrzywna-Jarnołtówek - 7 pairs, Konradów - 11 pairs, Podlesie-Gęstwina - 7 pairs (Kopij 2014b).

Phoenicurus phoenicurus. In 2010, 26 breeding pairs were recorded, most of them nested near Pokrzywna and Jarnołtówek; in Głuchołazy - 2-4 pairs (Kopij 2014b); Prudnik - 5-7 pairs (Kopij 2013b); Podlesie - 3 pairs (Kopij 2014b) (Fig. 13).

Saxicola rubetra. Fairly common in farmlands.

Saxicola rubicola. In 2010, 18 breeding pairs were recorded (Fig. 14). In 1978-87 - not recorded at al (Dyrcz et al. 1991).

Oenanthe oenanthe. During the years 1989-1993 one pair nested in a sand-pit S of Jasiona (Kopij 1999), where it nested also in 2010.

Turdus merula. Subdominant (3.2\%) species in all forests. Common also in human settlements: Prudnik - 30-50 pairs (Kopij 2013c); Głuchołazy - 20 pairs in April 2010 (Kopij 2014b); Konradów - 9 pairs (Kopij 2014b); Moszczanka - 6 pairs, Łąka Pr. - 5 pairs (Kopij 2014a).

Turdus pilaris. Fairly common in farmlands. It nested also in Głuchołazy - 4-6 pairs (Kopij 2014b), Prudnik - 46 pairs (Kopij 2013c) and Konradów - 6 pairs (Kopij 2014b).

Turdus philomelos. Subdominant in all forests $(2.8 \%)$. Uncommon in human settlements: Prudnik - 4-6 pairs (Kopij 2013b); Głuchołzay - 2-3 pairs (Kopij 2014b); Pokrzywna-Jarnołtówek - 2 pairs (Kopij 2014b); Moszczanka - 4 pairs.

Turdus viscivorus. In 2010, 36 breeding pairs were recorded (Fig. 15), and the whole population was estimated at 40-60 pairs. The proportion of T. merula : T. philomelos : T. viscivorus was $0.44: 0.46: 0.10(\mathrm{n}=423)$.

Locustella naevia. Thiemann (1887) reported it as breeding near Głuchołazy. In 2010, 20 breeding pairs were recorded (Fig. 16).

Locustella fluviatilis. In 2010, 11 breeding pairs were recorded (Fig. 16).

Locustela luscinioides. During the years 1978-1987, it was recorded in one breeding site on Prudnik near Dytmarów. Not recorded in 2010.

Acrocephalus schoenobaenus. 28.04.2010 one singing male was heard in a marshland N of Krzyżkowice.

Acrocephalus palustris. Common in farmlands and on forest edges.

Acrocephalus scirpaceus. In 2010, it was recorded as breeding in reedbeds between Dytmarów and Krzyżkowice (2-3 pairs).

Acrocephalus arundinaceus. In 2010, 5 pairs were recorded in a water reservior S of Prudnik, 4 pairs in Niemysłowice gravel pit, 3 pairs in a sand-pit between Trzebina and Skrzypiec, and 1 pair in a reedbed between Dytmarów and Krzyżkowice.

Hippolais icterina. Fairly common in human settlements, e.g. Prudnik - 2-5 pairs (Kopij 2013c); Głuchołazy - 25 pairs (Kopij 2014b), Konradów - 2 pairs (Kopij 2014b). Rare in forests. 
Sylvia curruca. Fairly common in human settlements: Prudnik - 7-12 pairs (Kopij 2013c); Głuchołazy - 7-10 pairs (Kopij 2014b); Trzebina - 5 pairs (Kopij 2014a). Rare in forests and farmlands.

Sylvia communis. Common in farmlands; uncommon in forests.

Sylvia borin. Fairly common in forests and farmlands.

Sylvia atricapilla. Dominant in all forests $(5.0-10.5 \% ; x=8.4)$; common also in human settlemnts, e.g. in Prudnik - 10-15 pairs (Kopij 2013b); Głuchołazy - 4-6 pairs (Kopij 2014b); Trzebina - 13 pairs (Kopij 2014a). The proportion between $S$. atricapilla and remaining Sylvia species was $0.88: 0.12(\mathrm{n}=335)$.

Phylloscopus sibilatrix. In Trzebina Forest, it was recorded as subdominant $(3.9 \%)$ and the most numerous Phylloscopus species; in other forests, it comprised less than $2 \%$.

Phylloscopus collybita. A dominant species (5.0-5.1\%) in Chrobry's Mt. and Bishop's Mt.; subdominant elsewhere; Prudnik - 15-20 pairs (Kopij 2013c); Głuchołazy - 32 pairs (Kopij 2014b). First arrival date: 19 March 2010, Niemysłowice Forest. In forests the proportion: P. collybita : P. sibilatrix : P. trochilus was 0.71 : $0.21: 0.08(\mathrm{n}=271)$.

Phylloscopus trochilus. Fairly common in forests, human settlements and farmlands. In Olszak Mt. and Charbielin Forest - 2.1\%; below 0.5\% elsewhere. In Konradów - at least 6 pairs in 2010 (Kopij 2014b).

Phylloscopus trochiloides. 25.05.1997 one singing male was recorded on Bystry Potok valley (Hebda 2001).

Regulus regulus. Dominant species in Chrobry's and Bishop's Mts., where spruce predominates; sudominant elsewhere; but in Trzebina Forest (mostly oaks) only $0.8 \%$.

Regulus ignicapillus. Subdominant in Bishop's Mt. $(2.4 \%) ;<1 \%$ in other forests. Single singing males were recorded in urban parks in Głuchołazy and Pokrzywna. The proportion between $R$. regulus and R. ignicapillus was $0.79: 0.21(\mathrm{n}=256)$. Arrival date: 20 March 2010 in Głuchołazy.

Muscicapa striata. Subdominant in all forests (2.4\%). In most villages: 1-2 pairs (Kopij 2014ab); Prudnik - 3-5 pairs (Kopij 2013c); Głuchołazy - 2-5 pairs (Kopij 2014b).

Ficedula albicollis. During the years 1978-87 - not recorded at all (Dyrcz et al. 1991). In 2010, 19 breeding pairs were recorded (Fig. 17).

Ficedula hypoleuca. In overall, it was much less numerous than the sibbling species. The proportion between $F$. albicollis and F. hypolecuca was $70.3: 29.7(\mathrm{n}=37)$. In the western part of the study area F. hypoleuca was as numerous as $F$. albicollis $(0.50: 050 ; \mathrm{n}=18)$, while in the eastern part the reverse was true $(89.5: 10.5 ; \mathrm{n}=19)$.

Ficedula parva. 25.05.2010 one singing male was heard in Bystry Potok valley in 'Cicha Dolina' nature reserve. During the years 1978-87 - not recorded (Dyrcz et al. 1991).

Aegithalos caudatus. Uncommon, below $0.7 \%$ of all breeding birds in forests.

Parus palustris. Fairly common.

Parus montanus. Rare.

Parus cristatus. Fairly common.

Parus ater. Dominant and the most numerous of all tit species (Paridae) in Chrobry's and Bishop's Mts.; subdominant in other forests.

Parus caeruleus. Subdominant in Olszak Mt., Charbielin Forest and Trzebina Forest; below 2\% in other forests. In Moszczanka - 14 pairs in 2010 (Kopij 2014a).

Parus major. A dominant species $(4.4-9.6 \% ; x=6.2)$ in all forests, except for Chrobry's Mt., where $4.4 \%$. The percentage proportion among P. major : P. ater : P. caeruleus : P. cristatus : P. palustris was $45.0: 33.7: 13.2$ : $5.2: 3.0(\mathrm{n}=796)$. Common also in human settlements, eg. in Moszczanka - at least 23 pairs in 2010 (Kopij 2014a).

Sitta europaea. A dominant species (4.3-9.6\%; $x=5.9)$ in all forests. In Prudnik - 7 pairs (Kopij 2013c); Głuchołazy - 6 pairs (Kopij 2014b). Not recorded in villages.

Certhia familiaris. Recorded as subdominant in most forests $(x=1.9 \%)$.

Certhia brachydactyla. Uncommon. The proportion between C. familiaris and C. brachydactyla was $86.8: 13.2$ $(n=121)$, in western part of the study area: $96.7: 3.3(n=61)$, in the eastern part: $76.7: 23.3(n=60)$.

Remiz pendulinus. During the years 1978-87 - not recorded. In 2010, single breeding pairs were recorded in willows near the water reservoir above Jarnołtówek, and on Prudnik River near Prudnik (Fig. 18).

Oriolus oriolus. In 2010, 38 pairs were recorded (Fig. 19).

Lanius collurio. Fairly common in farmlands.

Lanius excubitor. 28.04.2010 one individual was recorded on Prudnik River near Krzyżkowice; 17.06.2010 one individual was observed in a farmland S of Wierzbiec.

Garrulus glandarius. Fairly common. In particular forest, it comprised 1-2\% of all breeding birds.

Nucifraga caryocatactes. For the first time recorded in Opava Mts. on 12.09.1887 near Pokrzywna (Kollibay 1906). In 1990-92 - 4-5 pairs (Kopij 1994), but in 2010 not recorded.

Pica pica. Fairly common in human settlements: Prudnik - 3-10 pairs (Kopij 2013); Głuchołazy - 3-5 pairs (Kopij 2014b); Moszczanka-Łąka Prudnicka - 5 pairs (Kopij 2014a).

Corvus monedula. In 2010, it was recorded in Prudnik (20-40 pairs; Kopij 2013c), Głuchołazy (20-40 pairs; Kopij 2014b), Dytmarów (5 pairs) and Skrzypiec (1 pair). 
Corvus frugilegus. In 2010, a colony with c. 358 nests was established in a park in Prudnik, and another small one (20 nests) near the railway station in this town (Kopij 2013c). A breeding colony with 28 occupied nests was also established in a small park in Skłodowska Str. in Głuchołazy (Kopij 2014b).

Corvus cornix. In 2010, 13 breeding pairs were recorded, including 6 pairs on Prudnik River (Fig. 20).

Corvus corax. In 2010, 13 breeding pairs were recorded (Fig. 20). During the years 1978-87 - not recorded at al (Dyrcz et al. 1991).

Sturnus vulgaris. In most forests recorded as subdominant. Common also in human settlemnts.

Passer domesticus. Breeding recorded only in human settlements: Głuchołazy - 70-150 pairs (Kopij 2014b), including 33 pairs in the town centre (12 ha); Konradów - 45, Podlesie - 12, Jarnołtówek - 19, Pokrzywna 5, (Kopij 2014b); Trzebina >60 par, Moszczanka - 42, Łąka Prudnicka - 41; Dębina - 3 pairs (Kopij 2014a).

Passer montanus. Fairy common in human settlements.

Fringilla coelebs. The most common species in forests; strongly dominating over other species in all forests (10.1 17.2\%; $x=14.6 \%$ ); Prudnik - 10-20 pairs (Kopij 2013c); Głuchołazy - 13 pairs (Kopij 2014b), Konradów - 17 pairs (Kopij 2014b), Trzebina - 5 pairs (Kopij 2014a).

Serinus serinus. Common in human settlements, e.g.: Prudnik - 20-40 pairs (Kopij 2013c); Głuchołazy - 14 pairs (Kopij 2014b), Trzebina - 11 pairs (Kopij 2014a). Rare in forests.

Carduelis chloris. Common in human settlements, e.g.: Moszczanka - 17 pairs, Łąka Prudnicka - 8 pairs (Kopij 2014a), Konradów - 14 pairs (Kopij 2014b). Rare in forests.

Carduelis carduelis. Common in human settlements, e.g.: Moszczanka - 10 pairs, Łąka Prudnicka - 5 pairs (Kopij 2014a); Pokrzywna-Jarnołtówek - 9 pairs (Kopij 2014b). Common also in farmlands, but rare in forests.

Carduelis spinus. Uncommon.

Carduelis cannabina. Common in human settlements, e.g. in Moszczanka - 6 pairs, Łąka Pr. -8 pairs (Kopij 2014a).

Loxia curvirostra. Fairly common in spruce forests, especially on Chrobry Mt.

Loxia leucoptera. In 1889, a young individual was recorded in Schönwald near Głuchołazy, and near Pokrzywna in 1892 and 1902 (Kollibay 1906).

Carpodacus erythrinus. On 29.06.1999 one singing male was heard near water reservoir on Złoty Potok in Jarnołtówk (Hebda 2001).

Pyrrhula pyrrhula. Fairly common in spruce forests.

Coccothraustes coccothraustes. In most forests recorded as subdominant (1.9\%).

Emberiza citrinella. A dominant species in Olszak Mt. and Charbielin Forest (5.9\%); subdominant elsewhere; in Chrobry Mt. - only $0.2 \%$. Also fairly common in some villages, e.g. in Konradowa - 12 pairs, MoszczankaŁąka Pr. - 6 pairs (Kopij 2014a); but not recorded in Jarnołtówek and Pokrzywna (Kopij 2014b);

Emberiza hortulana. In 2010, 3 breeding sites were located: 3 singing males on a forest egdge SW of Krzyżkowice, one male S od Moszczanka on Szyniecki Potok, and one male between Wieszczyna and Pokrzywna along the Polish/Czech border (Fig. 19).

Emberiza schoeniclus. Fairy common in farmlands; 10-20 pairs. In 2010, one pair nested in a rape cultivation near Trzebina, far from any water bodies.

Miliaria calandra. Fairly common in farmlands. In 2010, more than 20 breeding pairs.

\section{Discussion}

\section{General characteristic of the breeding avifauna}

In 2010, a total of 116 breeding and two probably breeding bird species were recorded in Opava Mts (Table 2, Fig. 1-20). This comprises $62.5 \%$ of all breeding bird species recorded in Silesia during the years 1978-87 (based on Dyrcz et al. 1991) and 51.1\% of all breeding bird species recorded in Poland during the years 1990-2004 (based on Sikora et al. 2007). In comparison with other mountains in Sudety (Dyrcz \& Mikusek 1996; Mikusek 1996; Flousek \& Gramsz 1999; Mikusek \& Dyrcz 2003), this is quite a high number. However, it is important to point out, that in this study also the foothills were included as study area. This could increase the number of breeding species by some water birds. On the other hand the study period was restricted to one year only, and a few breeding species could passed undetected.

Out of 116 species recorded in 2010 in Opava Mts., Non-Passriformes comprised 33.9\%, while Passeriformes $-66.1 \%$. In the former group water birds ( 9 species), raptors (6 species) and woodpeckers $(7$ species) were the most representative groups. Among Passeriformes the most speciose were Turdidae (11 species), Fringillidae (10 species) and Paridae (8 species). 
Few species breed in Opava Mts. in denities higher than in other parts of Opole Silesia. The group includes Accipiter gentilis, Falco tinnunculus, Columba oenas, Motacilla cinerea, Cinclus cinclus, Saxicola rubicola, Turdus viscivorus, Regulus ignicapillus, Parus montanus and Loxia curvirostra.

\section{Changes in the breeding avifauna over the years 1880-2010}

Over the last 130 years (1880-2010), a total of 134 bird species were recorded as breeding in Opava Mts., which comprises $70.7 \%$ of Silesian (based on Dyrcz et al. 1991) and $57.9 \%$ of Polish breeding avifauna (based on Sikora et al. 2007). For three species, Circus aeruginosus, Phylloscopus trochiloides and Loxia leucoptera, there is no direct proof of their breeding. They can be regarded as possible breeding in Opava Mts. Cygnus olor, Chroicocephalus ridibundus, Sterna hirundo, Podiceps cristatus and Fulica atra were found to breed only in the foothills, while Aquila pomarina and Grus grus nested extralimitary in the Czech Republic, close to the Polish/Czech border.

Before 1990, but after 1945, the following species were recorded as new for the breeding avifauna of Opava Mts.: Streptopelia decaocto, Ciconia ciconia, Ciconia nigra, Corvus frugilegus, Locustella luscinioides (based on Pax 1925, Dyrcz et al. 1991). The following species were recorded as breeding for the first time in Opava Mts. during the years 1990-97: Bubu bubo, Corvus corax, Saxicola rubicola, Locustella fluviatilis, Ficedula albicollis, Acrocephalus schoenobaenus, and Emberiza hortulana (Kopij 1994, Hebda 2001). In 2010, the following species were recorded as breeding in Opava Mts. for the first time: Cygnus olor, Tachybaptus ruficollis, Podiceps cristatus, Chroicocephalus ridibunda, and Remiz pendulinus (this study).

During the years 1990-2010, for the following species decrease in numbers has been evidenced: Perdix perdix, Tetrastes bonasia, Tyto alba, Athene noctua, Corvus frugilegus, and Nycifraga caryocatactes, In the same period, increase in numbers has been documented for species such as: Accipiter gentilis, Falco tinnunculus, Columba oenas, Jynx torquilla, Dryocopus martius, Picus canus, Picus viridis, Motacilla cinerea, Luscinia megarhynchos, Phoenicurus phoenicurus, Saxicola rubicola, Locustella naevia, Locustella fluviatilis, Corvus corax and Corvus cornix.

\section{Protection of the avifauna}

Several bird species recorded in Opava Mts. are listed in Annex 1 of the Bird Directive of E. U. (Directive 79/409/EWG from 2 April 1979): Ciconia nigra, Ciconia ciconia, Pernis apivorus, Circus aeruginosus, Crex crex, Grus grus, Sterna hirundo, Alcedo atthis, Dryocopus

martius, Picus canus, Dendrocopos medius, Ficedula albicollis, Lanius collurio, Lulula arborea. Emberiza hortulana. Especially common are the woodpeckers and Ficedula albicollis.

The most serious threat for the breeding avifauna is the habitat (i.e. forest) destruction. In the last few decades a quick and large removal of old stands of trees, especially spruces, have been done in some places of the Chrobry Mt. and Prudnicki Forest. Affected species include woodpeckers, raptors, owls, Ficedula albicollis, and Columba oenas. The Prudnik River below the town of Prudnik and Złoty Potok below Jarnołtówek are badly polluted with the communal sewage and may pevent Alcedo atthis, Charadrius dubius, Actitis hypoleucos Cinclus cinclus, and Motacilla cinerea to breed there. Tourists and forest workers (felling trees in the breeding season) may negativelly affect the numbers of Bonasia bonasia, Grus grus, Ciconia nigra, Accipiter gentilis and Aquila pomarina.

Larger parts of the Opava Mts. are protected in the form of Landscape Park. There are also three reserves established within this Park (Kopij 2013a). Based on the distrribution maps of endangered, rare and protected species (Fig. 1-20), the following other areas are postulated to be protected in the form of nature reserve: the water reservoir and its surrounding on Złoty 
Potok above Jarnołtówek; Bystry Potok Valley from its source to the confluence with Złoty Potok; and the tree stand on the Lipowiec Mt. in Trzebnica Forest. The whole Prudnicki Las and its surroundings (meadows) is postulated to be protected as so called nature-landscape complex.

Table 2. Changes in the status and numbers of birds breeding in Opava Mts. over the years 1906-2010.

\begin{tabular}{|c|c|c|c|c|c|}
\hline Species & 1906-38 & $1990-92$ & $1995-96$ & 2010 & Trend \\
\hline Cygnus olor & - & - & - & 1 & \\
\hline Anas platyrhynchos & $*$ & $*$ & - & $*$ & \\
\hline Perdix perdix & $*$ & 3 & 3 & - & \\
\hline Coturnix coturnix & $*$ & - & $8-11$ & 5 & $\uparrow$ \\
\hline Phasianus colchicus & $*$ & $*$ & - & $*$ & \\
\hline Tachybaptus ruficollis & - & - & 1 & 1 & \\
\hline Podiceps cristatus & - & - & - & 1 & \\
\hline Ciconia nigra & - & 1 & 1 & - & \\
\hline Ciconia ciconia & - & $5-6$ & 12 & 6 & $\uparrow \downarrow$ \\
\hline Pernis apivorus & $?$ & - & $1 ?$ & - & \\
\hline Circus aeruginosus & - & - & - & $1 ?$ & \\
\hline Accipiter gentilis & $*$ & 5 & $4-5$ & 9 & $\uparrow$ \\
\hline Accipiter nisus & * & - & 1 & $1 ?$ & \\
\hline Buteo buteo & $*$ & 25 & $46-50$ & 32 & \\
\hline Aquila pomarina & - & - & $1 ?$ & (1) & \\
\hline Falco tinnunculus & $*$ & 3 & 7 & 7 & $\leftrightarrow$ \\
\hline Falco subbuteo & - & - & $1 ?$ & 1 & \\
\hline Crex crex & * & $1-2$ & 3 & 1 & $\leftrightarrow$ \\
\hline Gallinula chloropus & $?$ & - & - & $5-8$ & \\
\hline Fulica atra & $?$ & - & - & $7-8$ & \\
\hline Grus grus & - & - & - & $(1-2)$ & $\uparrow$ \\
\hline Charadrius dubius & $?$ & - & $3-5$ & 1 & $\downarrow$ \\
\hline Vanellus vanellus & $?$ & $6-8$ & 3 & 5 & $\downarrow$ \\
\hline Scolopax rusticola & * & $2 ?$ & $1 ?$ & $1 ?$ & \\
\hline Chroicocephalus ridibundus & - & - & - & $4-5$ & \\
\hline Sterna hirundo & - & - & - & $1 ?$ & \\
\hline Columba livia f. domestica & - & $?$ & * & $30-50$ & \\
\hline Columba oenas & * & 2 & 2 & 9 & $\uparrow$ \\
\hline Columba palumbus & * & $*$ & * & $*$ & \\
\hline Streptopelia decaocto & - & $>46$ & $*$ & $>70$ & \\
\hline Streptopelia turtur & * & $*$ & $*$ & 37 & \\
\hline Cuculus canorus & * & 6 & 17 & 23 & $\uparrow$ \\
\hline Tyto alba & $?$ & 2 & 1 & - & \\
\hline Athene noctua & $* ?$ & $1 ?$ & 1 & - & \\
\hline Bubo bubo & - & - & 1 & $?$ & \\
\hline Asio otus & $*$ & $?$ & 2 & $*$ & \\
\hline Strix aluco & $*$ & * & 16 & $*$ & \\
\hline Apus apus & $* ?$ & 40 & $*$ & $38-54$ & $\leftrightarrow$ \\
\hline Alcedo atthis & $*$ & - & 2 & 1 & \\
\hline Coracias garrulus & $*$ & - & - & - & \\
\hline Upupa ерорs & $?$ & - & $1 ?$ & 2 & \\
\hline Jynx torquilla & $*$ & - & 1 & 6 & $\uparrow$ \\
\hline Picus canus & 1 & 1 & 6 & 8 & $\uparrow$ \\
\hline Picus viridis & $*$ & 1 & $1-2$ & 6 & $\uparrow$ \\
\hline Dryocopus martius & $*$ & c. 10 & 12 & 14 & $\uparrow$ \\
\hline Dendrocopos major & $*$ & $*$ & $*$ & $*$ & \\
\hline Dendrocopos medius & $* ?$ & 4 & 12 & 11 & $\uparrow$ \\
\hline Dendrocopos minor & $* ?$ & 7 & $9-12$ & 7 & \\
\hline Alauda arvensis & $*$ & $*$ & $*$ & $*$ & \\
\hline Hirundo rustica & $*$ & $*$ & * & $>120$ & \\
\hline
\end{tabular}




\begin{tabular}{|c|c|c|c|c|c|}
\hline Delichon urbica & * & 400 & * & $250-350$ & $\leftrightarrow$ \\
\hline Anthus trivialis & *? & $*$ & * & $*$ & \\
\hline Anthus pratensis & $*$ & 2 & - & - & \\
\hline Anthus campestris & ? & - & - & 1 & \\
\hline Motacilla flava & * & - & 1 & $>10$ & $\uparrow$ \\
\hline Motacilla cinerea & * & $3-5$ & $12-13$ & 17 & $\uparrow$ \\
\hline Motacilla alba & $*$ & $25-30$ & $*$ & $*$ & \\
\hline Cinclus cinclus & $2-3$ & 4 & 8 & 7 & $\uparrow$ \\
\hline Troglodytes troglodytes & $*$ & $*$ & * & * & \\
\hline Prunella modularis & *? & * & * & * & \\
\hline Erithacus rubecula & $*$ & * & * & * & \\
\hline Luscinia megarhynchos & * & 8 & 2 & 20 & $\uparrow$ \\
\hline Phoenicurus ochruros & * & * & * & $>60$ & \\
\hline Phoenicurus phoenicurus & * & 4 & 10 & 26 & $\uparrow$ \\
\hline Saxicola rubetra & *? & $>6$ & $21-24$ & $*$ & \\
\hline Saxicola rubicola & - & 7 & 8 & 18 & $\uparrow$ \\
\hline Oenanthe oenanthe & ? & - & - & 1 & \\
\hline Turdus merula & * & * & * & * & \\
\hline Turdus pilaris & * & * & * & * & \\
\hline Turdus philomelos & * & $*$ & * & * & \\
\hline Turdus viscivorus & * & 15 & $32-35$ & 36 & \\
\hline Locustella naevia & * & 2 & 8 & 20 & $\uparrow$ \\
\hline Locustella fluviatilis & - & 2 & 7 & 11 & $\uparrow$ \\
\hline Acrocephalus schoenobaenus & - & - & - & 1 & \\
\hline Acrocephalus palustris & $* ?$ & * & * & * & \\
\hline Acrocephalus scirpaceus & *? & - & - & $2-3$ & \\
\hline Acrocephalus arundinaceus & *? & - & - & 13 & $\uparrow$ \\
\hline Hippolais icterina & $*$ & * & * & $*$ & \\
\hline Sylvia nisoria & *? & * & 1 & - & \\
\hline Sylvia curruca & $*$ & * & * & * & \\
\hline Sylvia communis & * & * & $*$ & * & \\
\hline Sylvia borin & * & * & * & * & \\
\hline Sylvia atricapilla & * & * & * & * & \\
\hline Phylloscopus sibilatrix & * & * & * & $*$ & \\
\hline Phylloscopus collybita & * & * & * & * & \\
\hline Phylloscopus trochilus & * & * & * & * & \\
\hline Phylloscopus trochiloides & - & - & $1 ?$ & - & \\
\hline Regulus regulus & * & $*$ & $*$ & * & \\
\hline Regulus ignicapillus & ? & * & * & * & \\
\hline Muscicapa striata & * & * & $*$ & * & \\
\hline Ficedula albicollis & - & * & 45 & 19 & $\downarrow ?$ \\
\hline Ficedula hypoleuca & * & * & $*$ & $*$ & \\
\hline Ficedula parva & $* ?$ & - & $5-6$ & - & \\
\hline Aegithalos caudatus & $*$ & * & $*$ & 1 & \\
\hline Parus palustris & * & * & * & $*$ & \\
\hline Parus montanus & * & * & * & * & \\
\hline Parus cristatus & * & * & * & * & \\
\hline Parus ater & * & * & * & * & \\
\hline Parus caeruleus & * & * & * & * & \\
\hline Parus major & $*$ & $*$ & $*$ & $*$ & \\
\hline Sitta europaea & * & * & * & * & \\
\hline Certhia familiaris & * & * & * & $*$ & \\
\hline Certhia brachydactyla & ? & * & * & * & \\
\hline Remiz pendulinus & - & - & - & 2 & $\uparrow$ \\
\hline Oriolus oriolus & * & $7-9$ & 24 & 38 & $\uparrow$ \\
\hline Lanius collurio & * & $*$ & $33-37$ & $*$ & \\
\hline Lanius excubitor & ? & 2 & 1 & 2 & \\
\hline Nucifraga cayocatactes & * & $4-5$ & $1-2$ & - & $\downarrow$ \\
\hline Garrulus glandarius & $*$ & $*$ & $*$ & - & \\
\hline Pica pica & * & 14 & * & * & \\
\hline
\end{tabular}




\begin{tabular}{|c|c|c|c|c|c|}
\hline Corvus monedula & $*$ & $30-33$ & $*$ & $26-46$ & \\
\hline Corvus frugilegus & - & 100 & $*$ & 28 & $\downarrow$ \\
\hline Corvus cornix & $*$ & 8 & 9 & 13 & $\uparrow$ \\
\hline Corvus corax & - & 2 & 9 & 13 & $\uparrow$ \\
\hline Sturnus vulgaris & $*$ & $*$ & $*$ & $*$ & \\
\hline Passer domesticus & $*$ & $*$ & $*$ & $*$ & \\
\hline Passer montanus & $*$ & $*$ & $*$ & $*$ & \\
\hline Fringilla coelebs & $*$ & $*$ & $*$ & $*$ & \\
\hline Serinus serninus & $*$ & 60 & $*$ & $*$ & \\
\hline Carduleis chloris & $*$ & $*$ & $*$ & $*$ & \\
\hline Carduelis carduelis & $*$ & $*$ & $*$ & $*$ & \\
\hline Carduelis spinus & $?$ & $8-9$ & $*$ & $*$ & \\
\hline Carduelis cannabina & $*$ & $*$ & $*$ & $*$ & \\
\hline Loxia curvirostra & $*$ & $*$ & $>2$ & $>10$ & $\uparrow$ \\
\hline Loxia leucoptera & $* ?$ & - & - & - & \\
\hline Carpodacus erythrinus & $?$ & - & $1 ?$ & - & \\
\hline Pyrrhula pyrrhula & $?$ & $*$ & $10-11$ & $*$ & \\
\hline Coccothraustes coccothraustes & $*$ & $*$ & $*$ & $*$ & \\
\hline Emberiza citrinella & * & $*$ & $*$ & $*$ & \\
\hline Emberiza hortulana & - & 4 & 7 & 5 & $\leftrightarrow$ \\
\hline Emberiza schoeniclus & $?$ & 1 & 1 & $10-20$ & $\uparrow$ \\
\hline Miliaria calandra & - & 1 & $4-5$ & $>20$ & $\uparrow$ \\
\hline
\end{tabular}

Based on literatute, four study periods were distinguished:

I: 1906-1938 based on Kollibay (1906), Pax (1925) and Jitschin (1938)

II: 1990-92 based on Kopij (1994)

III: 1995-96 basedon Hebda (2000)

III: 2010 based on this study and Kopij (2014).

Trend (during the years 1990-2010): $\uparrow$-increase, $\downarrow$ - decrease, $\leftrightarrow-$ stable, -- no recorded Please note, in 2010, foothills were also included in the study area.

Explanatory notes for Figs 1-20: Fig. 1. Cotunrix coturnix (yellow triangles) and Vanellus vanellus (red dots) breeding pairs in Opava Mts. in 2010; Fig. 2. Ciconia ciconia nests (red dots: nests with fledglings, yellow dots: occupied nests without fledglings) in Opava Mts. in 2010; Fig. 3. Accipiter gentilis breeding pairs in Opava Mts. in 2010; Fig. 4. Distribution of Accipiter nisus (purple square), Falco tinnunculus (red dots) and Falco subbuteo (yellow triangle) breeding pairs in Opava Mts. in 2010; Fig. 5. Buteo buteo breeding pairs in Opava Mts. in 2010; Fig. 6. Distribution of Streptopelia turtur (red dots) and Columba oenas (yellow triangles) breeding pairs in Opava Mts. in 2010; Fig. 7. Cuculus canorus males in Opava Mts. in 2010; Fig. 8. Dendrocopos medius (red dotes), Dendrocopos minor (yellow triangles) and Jynx torquilla (purple squares) breeding pairs in Opava Mts. in 2010; Fig. 9. Dryocopus martius (red dots), Picus canus (yellow squares) and Picus viridis (purple squares) breeding pairs in Opava Mts. in 2010; Fig. 10. Distribution of Motacilla cinerea breeding pairs in Opava Mts. in 2010; Fig. 11. Cinclus cinclus breeding pairs in Opava Mts. in 2010; Fig. 12. Luscinia megarhynchos breeding pairs in Opava Mts. in 2010; Fig. 13. Phoenicurus phoenicurus breeding pairs in Opava Mts. in 2010; Fig. 14. Saxicola rubicola breeding pairs in Opava Mts. in 2010; Fig. 15. Turdus viscivorus breeding pairs in Opava Mts. in 2010; Fig. 16. Locustella naevia (red dots) and Locustella fluviatilis (yellow triangles) breeding pairs in Opava Mts. in 2010; Fig. 17. Ficedula albicollis breeding pairs in Opava Mts. in 2010; Fig. 18. Remiz pendulinus (yellow triangles) and Emberiza hortulana (red dotes) breeding pairs in Opava Mts. in 2010; Fig. 19. Oriolus oriolus breeding pairs in Opava Mts. in 2010; Fig. 20. Corvus cornix (red dotes) and Corvus corax (yellow triangles) breeding pairs in Opava Mts. in 2010. 

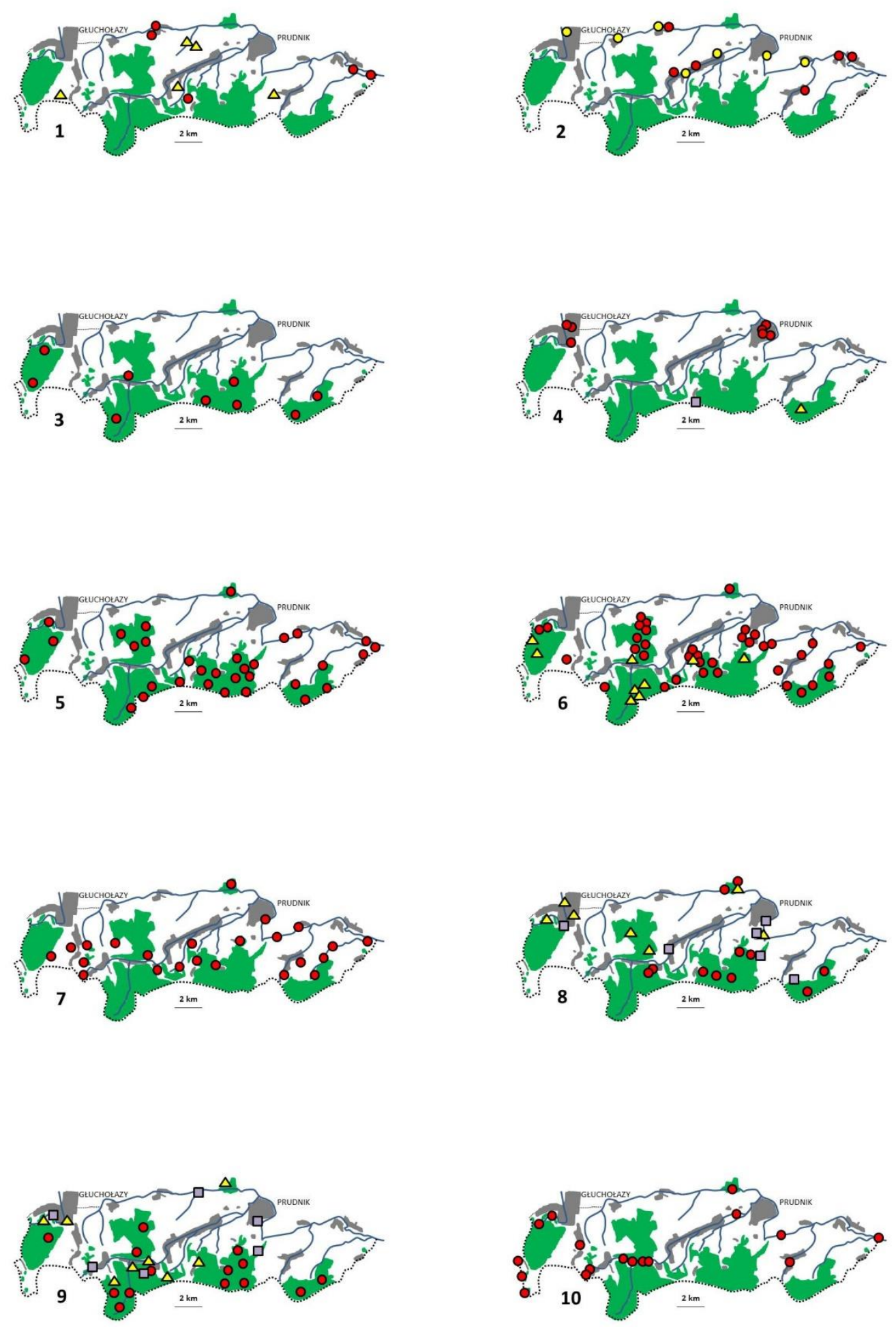

Figs 1-10: Map of distribution of birds in Opava Mts and their foothills, Opole Silesia. For explanatory notes see page 243. 

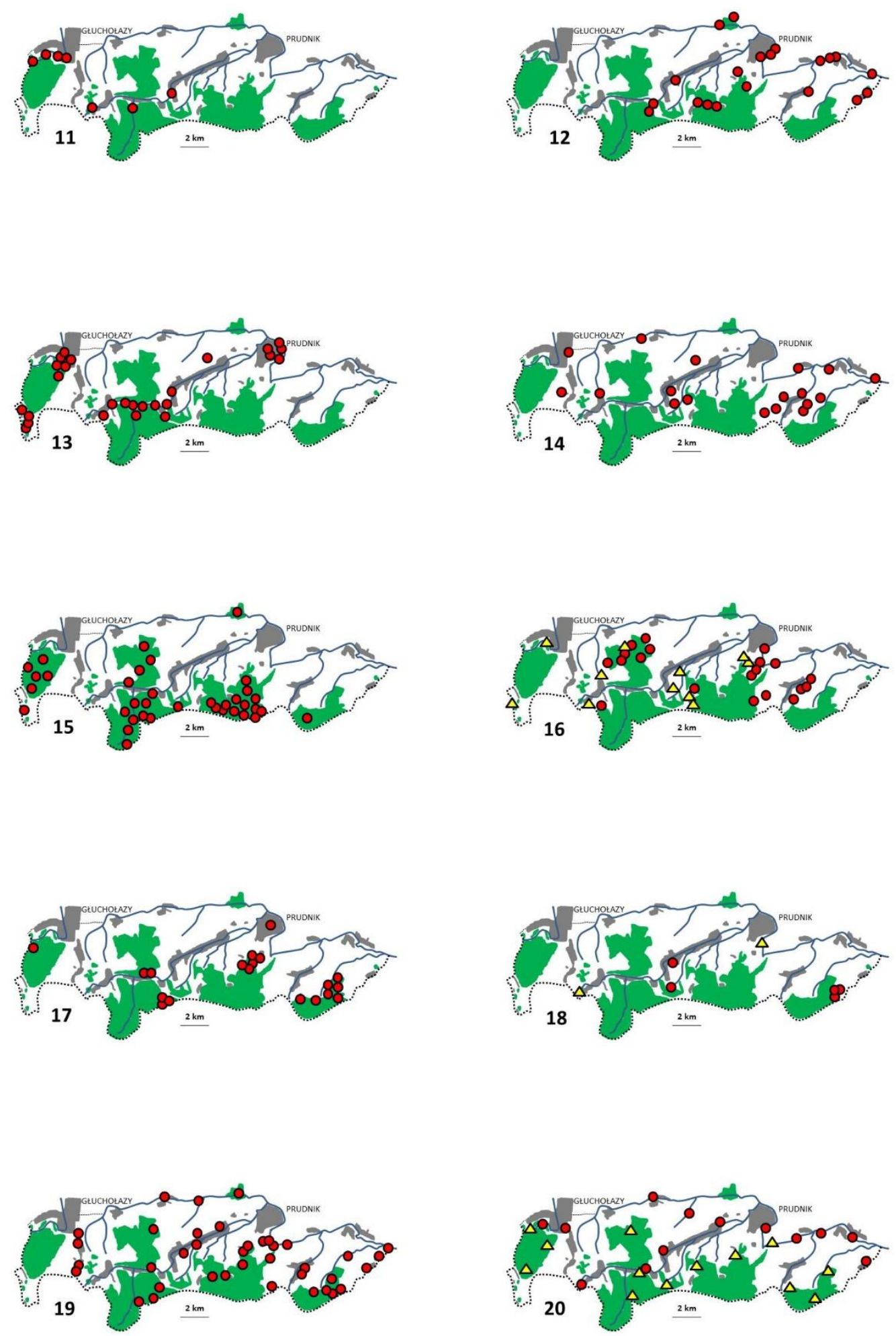

Figs 11-20: Map of distribution of birds in Opava Mts and their foothills, Opole Silesia. For explanatory notes see page 243 . 
Table 3: Results of counting breeding birds by mean of line transect method in larger forests in Opava Mountains and foothills in 2010. Dominant species are indicated with bold case. $\mathrm{Nt}$ - total number of breeding pairs recorded in all three counts, $\mathrm{N}_{\max }$ - maximal number of breeding pairs recorded in whatever of the three counts conducted.

\begin{tabular}{|c|c|c|c|c|c|c|c|c|c|c|c|c|c|c|c|c|c|c|c|c|c|c|c|c|}
\hline \multirow{3}{*}{$\begin{array}{l}\text { Species } \downarrow \\
\quad \text { Surface } \rightarrow \\
\end{array}$} & \multicolumn{4}{|c|}{ Chrobry's Mt. } & \multirow{2}{*}{\multicolumn{4}{|c|}{ Bishop's Mt. }} & \multicolumn{4}{|c|}{$\begin{array}{l}\text { Olszak and } \\
\text { Charbielin } \mathrm{F} \text {. }\end{array}$} & \multicolumn{4}{|c|}{ Prudnik F. } & \multicolumn{4}{|c|}{ Trzebina Forest } & & & Total & \\
\hline & & c. $65 \mathrm{C}$ & 0 ha & & & & & & & c. 75 & & & & c. 100 & 00 ha & & & c. 50 & 0 ha & & & & $4000 \mathrm{~h}$ & \\
\hline & $\mathrm{Nt}$ & $\%$ & $N_{\max }$ & $\%$ & $\mathrm{Nt}$ & $\%$ & $\mathrm{~N}_{\max }$ & $\%$ & $\mathrm{Nt}$ & $\%$ & $N_{\max }$ & $\%$ & $\mathrm{Nt}$ & $\%$ & $N_{\max }$ & $\%$ & $\mathrm{Nt}$ & $\%$ & $N_{\max }$ & $\%$ & $\mathrm{Nt}$ & $\%$ & $N_{\max }$ & $\%$ \\
\hline Accipiter gentilis & 0 & 0 & 0 & 0 & 0 & 0 & 0 & 0 & 1 & 0,1 & 1 & 0,2 & 2 & 0,1 & 2 & 0,2 & 1 & 0,1 & 1 & 0,2 & 4 & 0,07 & 4 & 0,12 \\
\hline Accipiter nisus & 0 & 0 & 0 & 0 & 0 & 0 & 0 & 0 & 0 & 0 & 0 & 0 & 1 & 0,1 & 1 & 0,1 & 0 & 0 & 0 & 0 & 1 & 0,02 & 1 & 0,03 \\
\hline Aegithalos caudatus & 3 & 0,4 & 2 & 0 & 5 & 0,4 & 3 & 0,4 & 6 & 0,7 & 4 & 0,7 & 5 & 0,3 & 3 & 0,3 & 3 & 0,3 & 3 & 0,5 & 22 & 0,41 & 15 & 0,45 \\
\hline Anas platyrhynchos & 4 & 0,5 & 3 & 1 & 0 & 0 & 0 & 0 & 0 & 0 & 0 & 0 & 0 & 0 & 0 & 0 & 0 & 0 & 0 & 0 & 4 & 0,07 & 3 & 0,09 \\
\hline Anthus trivilais & 1 & 0,1 & 1 & 0 & 1 & 0,1 & 1 & 0,1 & 9 & 1,1 & 7 & 1,2 & 4 & 0,3 & 4 & 0,5 & \begin{tabular}{|l|l|}
15 \\
\end{tabular} & 1,7 & 15 & 2,4 & 30 & 0,56 & 28 & 0,85 \\
\hline Buteo buteo & 4 & 0,5 & 4 & 1 & 5 & 0,4 & 3 & 0,4 & 8 & 0,9 & 3 & 0,5 & 18 & 1,2 & 7 & 0,8 & 10 & 1,1 & 6 & 1 & 45 & 0,83 & 23 & 0,7 \\
\hline Carduelis carduelis & 0 & 0 & 0 & 0 & 2 & 0,1 & 1 & 0,1 & 2 & 0,2 & 2 & 0,4 & 3 & 0,2 & 3 & 0,3 & 1 & 0,1 & 1 & 0,2 & 8 & 0,15 & 7 & 0,21 \\
\hline Carduelis chloris & 6 & 0,7 & 5 & 1 & 10 & 0,7 & 5 & 0,7 & 8 & 0,9 & 4 & 0,7 & 7 & 0,5 & 7 & 0,8 & 1 & 0,1 & 1 & 0,2 & 32 & 0,59 & 22 & 0,67 \\
\hline Carduelis spinus & 0 & 0 & 0 & 0 & 1 & 0,1 & 1 & 0,1 & 0 & 0 & 0 & & 0 & 0 & 0 & 0 & 0 & c & 0 & & 1 & 0,02 & 1 & 0,03 \\
\hline Ccuculus canorus & 0 & 0 & 0 & 0 & 5 & 0,4 & 4 & 0,5 & 4 & 0,5 & 4 & 0,7 & 10 & 0,7 & 10 & 1,2 & 5 & 0,6 & 5 & 0,8 & 24 & 0,44 & 23 & 0,7 \\
\hline Certhia brachydactyla & 1 & 0,1 & 1 & 0 & 0 & 0 & 0 & 0 & 1 & 0,1 & 1 & 0,2 & 9 & 0,6 & 4 & 0,5 & 5 & 0,6 & 3 & 0,5 & 16 & 0,3 & 9 & 0,27 \\
\hline Certhia familiaris & 19 & 2,3 & 12 & 2 & 29 & 2,2 & 14 & 1,8 & 11 & 1,3 & 6 & 1,1 & 32 & 2,1 & 19 & 2,2 & \begin{tabular}{|l|l}
14 \\
\end{tabular} & 1,6 & 7 & 1,1 & 105 & 1,95 & 58 & 1,76 \\
\hline Cinclus cinclus & 1 & 0,1 & 1 & 0 & 2 & 0,1 & 1 & 0,1 & 0 & 0 & 0 & 0 & 0 & 0 & 0 & 0 & 0 & 0 & 0 & & 3 & 0,06 & 2 & 0,06 \\
\hline Coccothraustes cocc. & 18 & 2,2 & 9 & 2 & 32 & 2,4 & 21 & 2,8 & 13 & 1,5 & 11 & 2 & 16 & 1,1 & 7 & 0,8 & 16 & 1,8 & 13 & 2,1 & 95 & 1,76 & 61 & 1,85 \\
\hline Columba oena & 3 & 0,4 & 3 & 1 & 4 & 0,3 & 4 & 0,5 & 1 & 0,1 & 1 & 0,2 & 2 & 0,1 & 2 & 0,2 & 0 & 0 & 0 & 0 & 10 & 0,19 & 10 & 0,3 \\
\hline Columba pamumbus & 9 & 1,1 & 5 & 1 & 19 & 1,4 & 9 & 1,2 & 13 & 1,5 & 7 & 1,2 & 20 & 1,3 & 8 & 0,9 & 5 & 0,6 & 3 & 0,5 & 66 & 1,22 & 32 & 0,97 \\
\hline Corvus corax & 4 & 0,5 & 2 & 0 & 3 & 0,2 & 3 & 0,4 & 3 & 0,4 & 1 & 0,2 & 7 & 0,5 & 5 & 0,6 & 7 & 0,8 & 4 & 0,6 & 24 & 0,44 & 15 & 0,45 \\
\hline Corvus cornix & 1 & 0,1 & 1 & 0 & 0 & 0 & 0 & 0 & 0 & 0 & 0 & 0 & 0 & 0 & 0 & 0 & 0 & 0 & 0 & 0 & 1 & 0,02 & 1 & 0,03 \\
\hline Dendrocopos major & 45 & 5,4 & 22 & 4 & 43 & 3,2 & 16 & 2,1 & 45 & 5,3 & 19 & 3,4 & 87 & 5,8 & 32 & 3,7 & 45 & 5,1 & 24 & 3,9 & 265 & 4,91 & 113 & 3,43 \\
\hline Dendrocopos medius & 0 & 0 & 0 & 0 & 0 & 0 & 0 & 0 & 0 & 0 & 0 & 0 & 4 & 0,3 & 2 & 0,2 & 1 & 0,1 & 1 & 0,2 & 5 & 0,09 & 3 & 0,09 \\
\hline Dendrocopos minor & 0 & 0 & 0 & 0 & 1 & 0,1 & 1 & 0,1 & 2 & 0,2 & 1 & 0,2 & 0 & 0 & 0 & 0 & 0 & 0 & 0 & 0 & 3 & 0,06 & 2 & 0,06 \\
\hline Dryocopus martius & 1 & 0,1 & 1 & 0 & 6 & 0,4 & 3 & 0,4 & 3 & 0,4 & 1 & 0,2 & 10 & 0,7 & 6 & 0,7 & 3 & 0,3 & 2 & 0,3 & 23 & 0,43 & 13 & 0,39 \\
\hline Emberiza citrinella & 1 & 0,1 & 1 & 0 & 29 & 2,2 & 21 & 2,8 & 70 & 8,2 & 33 & 5,9 & 38 & 2,5 & 20 & 2,3 & \begin{tabular}{|l|l|}
37 & \\
\end{tabular} & 4,2 & 22 & 3,6 & 175 & 3,24 & 97 & 2,94 \\
\hline Emberiza hortulana & 0 & 0 & 0 & 0 & 0 & 0 & 0 & 0 & 0 & 0 & 0 & 0 & 1 & 0,1 & 1 & 0,1 & 4 & 0,5 & 4 & 0,6 & 5 & 0,09 & 5 & 0,15 \\
\hline Erithacus rubecula & 65 & 7,8 & 41 & 8 & 114 & 8,5 & 57 & 7,5 & 83 & 9,7 & 66 & 12 & 100 & 6,7 & \begin{tabular}{|l|l|}
59 \\
\end{tabular} & 6,9 & \begin{tabular}{|l|l}
58 \\
\end{tabular} & 6,6 & 43 & 6,9 & 420 & 7,78 & 266 & 8,06 \\
\hline Falco subbuteo & 0 & 0 & 0 & 0 & 0 & 0 & 0 & 0 & 0 & 0 & 0 & 0 & 0 & 0 & 0 & 0 & 1 & 0,1 & 1 & 0,2 & 1 & 0,02 & 1 & 0,03 \\
\hline Ficedula albicollis & 1 & 0,1 & 1 & 0 & 6 & 0,4 & 6 & 0,8 & 2 & 0,2 & 2 & 0,4 & 8 & 0,5 & 8 & 0,9 & 9 & 1 & 9 & 1,5 & 26 & 0,48 & 26 & 0,79 \\
\hline Ficedula hypoleuca & 0 & 0 & 0 & 0 & 9 & 0,7 & 9 & 1,2 & 0 & 0 & 0 & 0 & 1 & 0,1 & 1 & 0,1 & 1 & 0,1 & 1 & 0,2 & 11 & 0,2 & 11 & 0,33 \\
\hline Ficedula parva & 0 & 0 & 0 & 0 & 1 & 0,1 & 1 & 0,1 & 0 & 0 & 0 & 0 & & 0 & 0 & 0 & 0 & 0 & 0 & 0 & 1 & 0,02 & 1 & 0,03 \\
\hline Fringilla coelebs & 135 & 16 & 65 & 13 & 320 & 24 & 130 & 17 & 86 & 10 & 57 & 10 & 273 & 18 & 131 & 15 & 197 & 22 & 100 & 16 & 1011 & 18,7 & 483 & 14,64 \\
\hline Garrulus glandarius & 13 & 1,6 & 10 & 2 & 15 & 1,1 & 8 & 1,1 & 19 & 2,2 & 7 & 1,2 & 23 & 1,5 & 10 & 1,2 & 15 & 1,7 & 15 & 2,4 & 85 & 1,58 & 50 & 1,52 \\
\hline Hipolais icterina & 0 & 0 & 0 & 0 & 0 & 0 & 0 & 0 & 0 & 0 & 0 & 0 & 3 & 0,2 & 3 & 0,3 & 0 & 0 & 0 & 0 & 3 & 0,06 & 3 &, 09 \\
\hline Jynx torquilla & 0 & 0 & 0 & 0 & 0 & 0 & 0 & 0 & 0 & 0 & 0 & 0 & 1 & 0,1 & 1 & 0,1 & 0 & 0 & 0 & 0 & 1 & 0,02 & 1 &, 03 \\
\hline Lanius collurio & 0 & 0 & 0 & 0 & 0 & 0 & 0 & 0 & 1 & 0,1 & 1 & 0,2 & 1 & 0,1 & 1 & 0,1 & 2 & 0,2 & 2 & 0,3 & 4 & 0,07 & 4 & 0,12 \\
\hline Locustella fluviatils & 1 & 0,1 & 1 & 0 & 2 & 0,1 & 2 & 0,3 & 1 & 0,1 & 1 & 0,2 & 4 & 0,3 & 4 & 0,5 & 0 & 0 & 0 & 0 & 8 & 0,15 & 8 & 0,24 \\
\hline Locustella naevia & 0 & 0 & 0 & 0 & 6 & 0,4 & 6 & 0,8 & 3 & 0,4 & 3 & 0,5 & 1 & 0,1 & 1 & 0,1 & 1 & 0,1 & 1 & 0,2 & 11 & 0,2 & 11 & 0,33 \\
\hline Loxia curvirostra & 12 & 1,4 & 7 & 1 & 13 & 1 & 7 & 0,9 & 2 & 0,2 & 2 & 0,4 & 10 & 0,7 & 5 & 0,6 & 4 & 0,5 & 3 & 0,5 & 41 & 0,76 & 24 & 0,73 \\
\hline Lulula arborea & 0 & 0 & 0 & 0 & 0 & 0 & 0 & 0 & 0 & 0 & 0 & 0 & 0 & 0 & 0 & 0 & 1 & 0,1 & 1 & 0,2 & 1 & 0,02 & 1 & 0,03 \\
\hline Motacilla cinerea & 1 & 0,1 & 1 & 0 & 1 & 0,1 & 1 & 0,1 & 1 & 0,1 & 1 & 0,2 & 0 & 0 & 0 & & 0 & 0 & 0 & 0 & 3 & 0,06 & 3 & 0,09 \\
\hline Muscicapa striata & 11 & 1,3 & 11 & 2 & 19 & 1,4 & 19 & 2,5 & 9 & 1,1 & 9 & 1,6 & 26 & 1,7 & 26 & 3 & 15 & 1,7 & 15 & 2,4 & 80 & 1,48 & 80 & 2,42 \\
\hline Oriolus oriolus & 0 & 0 & 0 & 0 & 0 & 0 & 0 & 0 & 1 & 0,1 & 1 & 0,2 & 9 & 0,6 & 9 & 1 & 5 & 0,6 & 5 & 0,8 & 15 & 0,28 & 15 & 0,45 \\
\hline Parus ater & 65 & 7,8 & 34 & 7 & 94 & 7 & 60 & 7,9 & 17 & 2 & 11 & 2 & 66 & 4,4 & 31 & 3,6 & 26 & 2,9 & 21 & 3,4 & 268 & 4,97 & 157 & 4,76 \\
\hline Parus caeruleus & 8 & 1 & 4 & 1 & 14 & 1 & 7 & 0,9 & 30 & 3,5 & 23 & 4,1 & 24 & 1,6 & 14 & 1,6 & 29 & 3,3 & 17 & 2,7 & 105 & 1,95 & 65 & 1,97 \\
\hline Parus cristatus & 10 & 1,2 & 8 & 2 & 9 & 0,7 & 5 & 0,7 & 4 & 0,5 & 3 & 0,5 & 16 & 1,1 & & 1 & & 0,2 & 2 & 0,3 & 41 & 0,76 & 27 & 0,82 \\
\hline Parus major & 47 & 5,7 & 22 & 4 & 68 & 5,1 & 38 & 5 & 80 & 9,4 & 54 & 9,6 & 106 & 7,1 & 53 & 6,2 & 57 & 6,4 & 36 & 5,8 & 358 & 6,64 & 203 & 6,15 \\
\hline Parus montanus & 0 & 0 & 0 & 0 & 1 & 0,1 & 1 & 0,1 & 7 & 0,8 & 4 & 0,7 & 2 & 0,1 & 1 & 0,1 & 3 & 0,3 & 2 & 0,3 & 13 & 0,24 & 8 & 0,24 \\
\hline Parus palustris & 10 & 1,2 & 7 & 1 & 4 & 0,3 & 3 & 0,4 & 2 & 0,2 & 1 & 0,2 & 7 & 0,5 & 5 & 0,6 & 1 & 0,1 & 1 & 0,2 & 24 & 0,44 & 17 & 0,52 \\
\hline Passer montanus & 0 & 0 & 0 & 0 & 0 & 0 & 0 & 0 & 0 & 0 & 0 & 0 & 1 & 0,1 & 1 & 0,1 & 0 & 0 & 0 & 0 & 1 & 0,02 & 1 & 0,03 \\
\hline Phoenicurus phoenic. & 1 & 0,1 & 1 & 0 & 4 & 0,3 & 4 & 0,5 & 0 & 0 & 0 & 0 & 0 & 0 & 0 & 0 & 0 & 0 & 0 & 0 & 5 & 0,09 & 5 & 0,15 \\
\hline Phylloscopus collybita & 42 & 5,1 & 23 & 5 & 52 & 3,9 & 38 & 5 & 26 & 3 & 18 & 3,2 & 54 & 3,6 & 28 & 3,3 & 20 & 2,3 & 19 & 3,1 & 194 & 3,6 & 126 & 3,82 \\
\hline Phylloscopus sibilatrix & 8 & 1 & 8 & 2 & 6 & 0,4 & 6 & 0,8 & 2 & 0,2 & 2 & 0,4 & 16 & 1,1 & 16 & 1,9 & 24 & 2,7 & 24 & 3,9 & 56 & 1,04 & 56 & 1,7 \\
\hline Phylloscopus trochilus & 0 & 0 & 0 & 0 & 4 & 0,3 & 4 & 0,5 & 12 & 1,4 & 12 & 2,1 & 2 & 0,1 & 2 & 0,2 & 3 & 0,3 & 3 & 0,5 & 21 & 0,39 & 21 & 0,64 \\
\hline Picus canus & 3 & 0,4 & 3 & 1 & 2 & 0,1 & 1 & 0,1 & 0 & 0 & 0 & 0 & 0 & 0 & 0 & 0 & 0 & 0 & 0 & 0 & 5 & 0,09 & 4 & 0,12 \\
\hline Picus viridis & 2 & 0,2 & 1 & 0 & 0 & 0 & 0 & 0 & 2 & 0,2 & 2 & 0,4 & 1 & 0,1 & 1 & 0,1 & 0 & 0 & 0 & 0 & 5 & 0,09 & 4 & 0,12 \\
\hline Prunella modularis & 3 & 0,4 & 2 & 0 & 7 & 0,5 & 3 & 0,4 & 13 & 1,5 & 11 & 2 & 10 & 0,7 & 5 & 0,6 & 3 & 0,3 & 2 & 0,3 & 36 & 0,67 & 23 & 0,7 \\
\hline Pyrrhula pyrrhula & 3 & 0,4 & 3 & 1 & 6 & 0,4 & 5 & 0,7 & 5 & 0,6 & 4 & 0,7 & 1 & 0,1 & 1 & 0,1 & 0 & 0 & 0 & 0 & 15 & 0,28 & 13 & 0,39 \\
\hline Regulus ignicapillus & 6 & 0,7 & 5 & 1 & 28 & 2,1 & 18 & 2,4 & 6 & 0,7 & 4 & 0,7 & 9 & 0,6 & 8 & 0,9 & 5 & 0,6 & 3 & 0,5 & 54 & 1 & 38 & 1,15 \\
\hline Regulus regulus & 43 & 5,2 & 19 & 4 & 78 & 5,8 & 40 & 5,3 & 28 & 3,3 & 17 & 3 & 46 & 3,1 & 23 & 2,7 & 7 & 0,8 & 5 & 0,8 & 202 & 3,74 & 104 & 3,15 \\
\hline
\end{tabular}




\begin{tabular}{|c|c|c|c|c|c|c|c|c|c|c|c|c|c|c|c|c|c|c|c|c|c|c|c|c|}
\hline \multirow{3}{*}{$\begin{array}{ll}\text { Species } \downarrow & \\
& \text { Surface } \rightarrow \\
\end{array}$} & \multicolumn{4}{|c|}{ Chrobry's Mt. } & \multicolumn{4}{|c|}{ Bishop's Mt. } & \multicolumn{4}{|c|}{$\begin{array}{l}\text { Olszak and } \\
\text { Charbielin F. }\end{array}$} & \multicolumn{4}{|c|}{ Prudnik F. } & \multicolumn{4}{|c|}{ Trzebina Forest } & \multicolumn{4}{|c|}{ Total } \\
\hline & \multicolumn{4}{|c|}{ c. 650 ha } & \multicolumn{4}{|c|}{ c. 1100 ha } & \multicolumn{4}{|c|}{ c. $750 \mathrm{ha}$} & \multicolumn{4}{|c|}{ c. 1000 ha } & \multicolumn{4}{|c|}{ c. 500 ha } & \multicolumn{4}{|c|}{ c. 4000 ha } \\
\hline & $\mathrm{Nt}$ & $\%$ & $\mathrm{~N}_{\max }$ & $\%$ & $\mathrm{Nt}$ & $\%$ & $\mathrm{~N}_{\max }$ & $\%$ & $\mathrm{Nt}$ & $\%$ & $\mathrm{~N}_{\max }$ & $\%$ & $\mathrm{Nt}$ & $\%$ & $\mathrm{~N}_{\max }$ & $\%$ & $\mathrm{Nt}$ & $\%$ & $\mathrm{~N}_{\max }$ & $\%$ & $\mathrm{Nt}$ & $\%$ & $\mathrm{~N}_{\max }$ & $\%$ \\
\hline Scolopax rusticolus & 2 & 0,2 & 1 & 0 & 0 & 0 & 0 & 0 & 1 & 0,1 & 1 & 0,2 & 0 & 0 & 0 & 0 & 0 & 0 & 0 & 0 & 3 & 0,06 & 2 & 0,06 \\
\hline Serinus serinus & 2 & 0,2 & 1 & 0 & 0 & 0 & 0 & 0 & 4 & 0,5 & 3 & 0,5 & 2 & 0,1 & 2 & 0,2 & 2 & 0,2 & 2 & 0,3 & 10 & 0,19 & 8 & 0,24 \\
\hline Sitta europaea & 81 & 9,8 & 48 & 10 & 71 & 5,3 & 44 & 5,8 & 39 & 4,6 & 24 & 4,3 & 103 & 6,9 & 47 & 5,5 & 33 & 3,7 & 30 & 4,8 & 327 & 6,06 & 193 & 5,85 \\
\hline Streptopelia turtur & 0 & 0 & 0 & 0 & 0 & 0 & 0 & 0 & 10 & 1,2 & 10 & 1,8 & 5 & 0,3 & 5 & 0,6 & 8 & 0,9 & 8 & 1,3 & 23 & 0,43 & 23 & 0,7 \\
\hline Strix aluco & 1 & 0,1 & 1 & 0 & 1 & 0,1 & 1 & 0,1 & 0 & 0 & 0 & 0 & 0 & 0 & 0 & 0 & 0 & 0 & 0 & 0 & 2 & 0,04 & 2 & 0,06 \\
\hline Sturnus vulgaris & 4 & 0,5 & 4 & 1 & 11 & 0,8 & 7 & 0,9 & 18 & 2,1 & 17 & 3 & 33 & 2,2 & 20 & 2,3 & 21 & 2,4 & 14 & 2,3 & 87 & 1,61 & 62 & 1,88 \\
\hline Sylvia atricapilla & 35 & 4,2 & 35 & 7 & 60 & 4,5 & 59 & 7,8 & 47 & 5,5 & 28 & 5 & 89 & 6 & 89 & 10 & 65 & 7,4 & 65 & 11 & 296 & 5,49 & 276 & 8,37 \\
\hline Sylvia borin & 2 & 0,2 & 2 & 0 & 2 & 0,1 & 2 & 0,3 & 8 & 0,9 & 8 & 1,4 & 0 & 0 & 0 & 0 & 4 & 0,5 & 4 & 0,6 & 16 & 0,3 & 16 & 0,48 \\
\hline Sylvia communis & 0 & 0 & 0 & 0 & 2 & 0,1 & 2 & 0,3 & 6 & 0,7 & 6 & 1,1 & 7 & 0,5 & 7 & 0,8 & 3 & 0,3 & 3 & 0,5 & 18 & 0,33 & 18 & 0,55 \\
\hline Sylvia curruca & 0 & 0 & 0 & 0 & 2 & 0,1 & 2 & 0,3 & 0 & 0 & 0 & 0 & 0 & 0 & 0 & 0 & 1 & 0,1 & 1 & 0,2 & 3 & 0,06 & 3 & 0,09 \\
\hline Sylvia nisoria & 0 & 0 & 0 & 0 & 1 & 0,1 & 1 & 0,1 & 1 & 0,1 & 1 & 0,2 & 0 & 0 & 0 & 0 & 0 & 0 & 0 & 0 & 2 & 0,04 & 2 & 0,06 \\
\hline Troglodytes troglodyt. & 15 & 1,8 & 11 & 2 & 31 & 2,3 & 16 & 2,1 & 10 & 1,2 & 6 & 1,1 & 34 & 2,3 & 23 & 2,7 & 2 & 0,2 & 1 & 0,2 & 92 & 1,71 & 57 & 1,73 \\
\hline Turdus merula & 40 & 4,8 & 24 & 5 & 18 & 1,3 & 9 & 1,2 & 27 & 3,2 & 16 & 2,8 & 59 & 4 & 35 & 4,1 & 41 & 4,6 & 21 & 3,4 & 185 & 3,43 & 105 & 3,18 \\
\hline Turdus philomelos & 22 & 2,7 & 12 & 2 & 49 & 3,7 & 19 & 2,5 & 37 & 4,3 & 19 & 3,4 & 50 & 3,4 & 23 & 2,7 & 36 & 4,1 & 18 & 2,9 & 194 & 3,6 & 91 & 2,76 \\
\hline Turdus pilaris & 0 & 0 & 0 & 0 & 0 & 0 & 0 & 0 & 0 & 0 & 0 & 0 & 0 & 0 & 0 & 0 & 1 & 0,1 & 1 & 0,2 & 1 & 0,02 & 1 & 0,03 \\
\hline Turdus viscivorus & 14 & 1,7 & 10 & 2 & 9 & 0,7 & 6 & 0,8 & 4 & 0,5 & 3 & 0,5 & 12 & 0,8 & 8 & 0,9 & 5 & 0,6 & 5 & 0,8 & 44 & 0,82 & 32 & 0,97 \\
\hline Total number of pairs & 829 & & 499 & & 1337 & & 758 & & 854 & & 564 & & 1491 & & 859 & & 884 & & 619 & & 5395 & & 3299 & \\
\hline
\end{tabular}

\section{References}

Bibby C.L., Burgess N.D. \& Hill D.A. (1992): Bird Census Techniques. Academic Press, London.

Czapulak A., Dziuba C., Fura M., Gramsz B., Kwiatkowski M., Sawicka E., Szeląg D. \& Witan K. (2008): Liczebność i rozmieszczenie pliszki górskiej Motacilla cinerea w polskiej części Sudetów. - Notatki Ornitologiczne 49: 141-152.

Dyrcz A., Grabiński W., Stawarczyk T. \& Witkowski J. (1991): Ptaki Śląska - monografia faunistyczna. Uniwersytet Wrocławski, Wrocław.

Dyrcz A. \& Mikusek R. (1996): Ptaki lęgowe Gór Stołowych na tle awifauny Sudetów i problemy ochrony ptaków w Parku Narodowym Gór Stołowych. Mat. z Sympozjum "SZCZELINIEC", pp. 215-219.

Dyrektywa 79/409/EWG z dn. 2.04.1979 r.

Dubiel K. (ed.) (1993): Monografia Parku Krajobrazowego „Góry Opawskie”. - Studia i Monografie (Opole) 209.

Flousek J. \& Gramsz B. (1999): Atlas ptaków lęgowych Karkonoszy. Vrchlabí.

Hebda G. (1997): Stanowisko puchacza Bubo bubo na Opolszczyźnie. - Chrońmy Przyrodę Ojczystą 53(2): 103 105.

- (2001): Ptaki lęgowe Parku Krajobrazowego Gór Opawskich. - Ptaki Śląska 13: 41-65.

Jitschin C. (1938): Die Vogelwelt im Wildgrund-Strandbadwinkel. - Oberschlesier 20: 260-262.

Kollibay P. (1906): Die Vögel der Preussischen Provinz Schlesien. Breslau.

Kondělka D. \& Petro R. (2007): Prvý známý př́ípad prokázaného hnízdění orla křiklavého (Aquila pomarina) na severní Moravě a ve Slezsku ve dvacétem století. - Čas. Slez. Muz. Opava (A) 56(2): 187.

- (2008): Prvé známé př́ípady prokázaného hnízdění jeřába popelavého (Grus grus) na Moravě a ve Slezsku. Sylvia 44: 67-68.

Kondracki J. (1994): Geografia Polski. Mezoregiony fizyczno-geograficzne. Warszwa: PAN.

Kopij G. (1990): Rozmieszczenie i liczebność płomykówki (Tyto alba) na południowej Opolszczyźnie. - Notatki Ornitologiczne 31: 43-52.

- (1991): Materiały do awifauny Śląska - Bocian biały (Ciconia ciconia) w byłym powiecie prudnickim. - Ptaki Śląska 8: 140-142.

- (1992): Bocian w rejonie Prudnika. - Tygodnik Prudnicki (Prudnik) 29 (26.07.1992): 8.

- (1994): Awifauna Parku Krajobrazowego "Góry Opawskie”. - Chrońmy Przyrodę Ojczystą 50(1): $26-32$.

- (1995): Ptaki miasta Prudnika. - Przyroda Śląska Opolskiego 1: 12-17.

- (1996): Awifauna lęgowa Przedgórza Paczkowskiego i Obniżenia Otmuchowskiego. - Chrońmy Przyrodę Ojczystą 52(1): 82-89.

- (1999): Awifauna lęgowa Płaskowyżu Głubczyckiego. - Chrońmy Przyrodę Ojczystą 55(2): 34-51.

- (2003): Wyniki inwentaryzacji gniazd bociana białego Ciconia ciconia na Ziemi Niemodlińskiej, Nyskiej i Prudnickiej w latach 1974-1991. - Przyroda Śląska Opolskiego 9: 1-7.

- (2005): Zmiany w awifaunie lęgowej dawnego powiatu Jesenik na Śląsku Opawskim w II połowie XX wieku. Przyroda Śląska Opolskiego 11: 9-20.

- (2006): Zmiany w awifaunie lęgowej okolic Osobłogi na Śląsku Opawskim w II połowie XX wieku. - Przyroda Śląska Opolskiego 12: 24-30. 
- (2007a): Osobliwości florystyczne i faunistyczne Euroregionu Pradziad. W: Euroregion Pradziad. Prudnik: Stowarzyszenie Gmin Polskich Euroregionu Pradziad, pp. 133-182.

- (2007b): Rozmieszczenie pionowe ptaków w Wysokich Jesionikach. - Przyroda Śląska Opolskiego 13: 24-26.

- (2011): Wyniki ankiety dotyczącej występowania i liczebności wybranych gatunków gadów, ptaków i ssaków na Górnym Śląsku i na Śląsku Opolskim. - Przyroda Śląska Opolskiego 17: 1-13.

- (2013a). Ptaki lęgowe rezerwatów przyrody „Cicha Dolina”, „Las Bukowy” i „Nad Białką” w Górach Opawskich. - Przyroda Śląska Opolskiego 19: 30-31.

- (2013b): Badania ilościowe nad ptakami lęgowymi lasów, zadrzewień i parków Ziemi Prudnickiej. - Przyroda Śląska Opolskiego 19: 1-14.

- (2013c): Ptaki lęgowe Prudnika w 2010 roku. - Przyroda Śląska Opolskiego 19: 15-26.

- (2014a): Ptaki lęgowe w wioskach Ziemi Prudnickiej w latach 2008-2009. - Przyroda Śląska Opolskiego 20: 112.

- (2014b): Ptaki lęgowe Głuchołaz i okolicznych wiosek. - Przyroda Śląska Opolskiego 20: 13-24.

- (2017): Wyniki inwentaryzacji gniazd bociana białego Ciconia ciconia na Ziemi Prudnickiej w latach $2007-$ 2009. - Przyroda Śląska Opolskiego 22: 14-17.

Kopij G., Jeszka W. \& Jakubiec Z. (2001). Wyniki inwentaryzacji gniazd bociana białego Ciconia ciconia na Śląsku Opolskim w drugiej połowie XX wieku. - Przyroda Śląska Opolskiego 7: 1-36.

Kopij G. \& Profus P. (2014): Rozmieszczenie i liczebnośc kuraków leśnych (Galliformes) na Śląsku w latach 2002-2014 oraz zmiany ich liczebności w ostatnich 140 latach. - Chrońmy Przyrodę Ojczystą 70(5): 387-409.

Kutter P. \& Kollibay P. (1882): V. Jahresbericht (1880) des Ausschusses für Beobachtungsstationen der Vögel Deutschlands: [Ornithologische Beobachtungen aus der Umgegend von Neustadt $\mathrm{O} / \mathrm{S}$ ]. - Journal für Ornithologie 30(1): 18-109.

- (1883): VI. Jahresbericht (1881) des Ausschusses für Beobachtungsstationen der Vögel Deutschlands: [Ornithologische Beobachtungen aus der Umgegend von Neustadt O/S] - Journal für Ornithologie 31(1): 1376.

Mikusek R. (1996): Ptaki lęgowe Gór Bystrzyckich. - Ptaki Śląska 11: 81-114.

Mikusek R. \& Dyrcz A. (2003): Ptaki Gór Stołowych. - Notatki Ornitologiczne 44: 89-119

Pax F. (1925): Wirbeltierfauna von Schlesien. Gebrüder Borntraeger, Berlin.

Sikora A., Rohde Z., Gromadzki M., Neubauer G. \& Chylarecki P. (eds) (2007): Atlas rozmieszczenia ptaków lęgowych Polski 1985-2004. Poznań, Bogucki Wyd. Nauk.

Thiemann A. (1887): Ornithologische Beobachtungen in Ziegenhals, Kr. Neisse. In: Blasius R. \& Reichenow A. (ed.). X Jahresbericht [1885]. - Journal für Ornithologie 35.

Author's address: Grzegorz Kopij, Department of Veretbrate Ecology, Wrocław University of Environmental \& Life Sciences, Ul. Kożuchowska 5b, 31-051 Wrocław, Poland E-mail: grzegorz.kopij@up.wroc.pl

Department of Integrated Environmetal Scince, University of Namibia, Ogongo Capmus Oshakati, Namibia

E-mail: gkopij@unam.na 